\title{
Modelling respiration of packaged fresh-cut 'Rocha' pear as affected by oxygen concentration and temperature
}

\author{
M. Helena Gomes ${ }^{\text {a }}$, Randolph M. Beaudry ${ }^{\text {b }}$, Domingos P.F. Almeida ${ }^{\text {a,c, }, *}$, F. Xavier Malcata ${ }^{a}$ \\ ${ }^{a}$ Escola Superior de Biotecnologia, Universidade Católica Portuguesa, R. Dr. António Bernardino de Almeida, 4200-072 Porto, Portugal \\ ${ }^{\mathrm{b}}$ Department of Horticulture, Michigan State University, Plant and Soil Sciences Building, East Lansing, MI 48824-1325, USA \\ ${ }^{\mathrm{c}}$ Faculdade de Ciências, Universidade do Porto, Rua do Campo Alegre, 4169-007 Porto, Portugal
}

Keywords:

Film permeability

Minimal processing

Modified atmosphere packaging

Pyrus communis

Respiratory quotient

\begin{abstract}
A B S T R A C T
Respiration rates were measured in fresh-cut 'Rocha' pear (Pyrus communis L.) stored at four temperatures $\left(0,5,10\right.$ and $\left.15{ }^{\circ} \mathrm{C}\right)$ and with oxygen partial pressures ranging from 0 to $18 \mathrm{kPa}$. Respiratory quotient and ethanol production were used to determine the fermentation threshold. The oxygen concentration effect on the respiration rate was accurately described using Michaelis-Menten kinetics, without noncompetitive inhibition by $\mathrm{CO}_{2}$, and the effect of temperature on the respiration rate was well modelled by exponential functions. The oxygen level at which respiration was half its maximum (apparent $K_{\mathrm{m}, \mathrm{O}_{2}}$ ) was similar to or only slightly greater than the fermentation threshold. The narrow range of oxygen between $K_{\mathrm{m} . \mathrm{O}_{2}}$ and the fermentation threshold, suggests that modified atmosphere packaging technology has a limited applicability toward extension of the shelf-life of fresh-cut 'Rocha' pear.
\end{abstract}

\section{Introduction}

Respiration is a central process in fruit metabolism: it provides energy and carbon skeletons for the anabolic reactions that occur during maturation and ripening, and for cell maintenance during storage. Besides its physiological importance, knowledge of fruit respiratory parameters possesses a technological relevance, particularly toward development of modified atmosphere packaging (MAP). Fruit respiration rate is affected by a number of factors, among which temperature and oxygen partial pressure exert strong effects (Fonseca et al., 2002). In fresh-cut fruit wounding enhances the respiration rate as part of the healing and ethylene responses (Brecht, 1995).

Fresh-cut processing often uses barrier technologies to modify atmosphere composition, prevent contamination, and reduce water loss (Kader et al., 1989). Since fresh-cut fruit respire, hermetically-sealed barriers used in these convenience products result in a modified atmosphere inside the package. Since MAP can extend the shelf-life and marketing period of fresh-cut fruit (Bai et al., 2001; Martínez-Ferrer et al., 2002) a great deal of effort has been dedicated to develop and test appropriate packages, and to optimize oxygen and carbon dioxide partial pressures inside the pack-

* Corresponding author. Address: Faculdade de Ciências, Universidade do Porto, Rua do Campo Alegre, 4169-007 Porto, Portugal. Tel.: +351 22 0402000; fax: +351 220402009.

E-mail address: dalmeida@fc.up.pt (D.P.F. Almeida). ages (Kader et al., 1989; Fonseca et al., 2002). A number of studies encompassing packaging films and geometries have assessed $\mathrm{O}_{2}$ concentration versus produce quality, in order to empirically find the best package (Bai et al., 2003; Del Nobile et al., 2007; SolivaFortuny et al., 2007; Teixeira et al., 2007). An alternative approach to the trial-and-error, should data be available, is to deduce optimal packaging geometry and film permeability based on the produce respiration rate (Lakakul et al., 1999; Jacxsens et al., 2000), as affected by oxygen concentration and temperature.

Respiration rates of fresh-cut pear were reported for 'd'Anjou', 'Bartlett', 'Bosc' and 'Red Anjou' cultivars stored in air and in $2 \mathrm{kPa}$ oxygen (Gorny et al., 2000). Values range between 0.07 0.22 and $0.27-0.53 \mathrm{mmol} \mathrm{CO}_{2} \mathrm{~kg}^{-1} \mathrm{~h}^{-1}$, respectively at 0 and $10^{\circ} \mathrm{C}$, rising to $0.86-1.63 \mathrm{mmol} \mathrm{CO}_{2} \mathrm{~kg}^{-1} \mathrm{~h}^{-1}$ at $20^{\circ} \mathrm{C}$. However, detailed information on the effect of oxygen concentration on the respiration of fresh-cut pear at different temperatures is still unavailable.

The impact of MAP on fresh-cut produce has been shown to be effective for some commodities; however benefits have not been demonstrated for fresh-cut pear. Further, the requirement for packaging fresh-cut fruit in sealed packages, to maintain produce safety and quality, will result in a modified atmosphere. Therefore, it is essential to quantify the relationship between oxygen concentration and respiration rate for fresh-cut 'Rocha' pear, stored at different temperatures, and to test respiratory models that would allow the design of MAP for fresh-cut pear at temperatures normally found during processing and distribution. 


\begin{tabular}{|c|c|c|c|}
\hline \multicolumn{4}{|c|}{ Nomenclature } \\
\hline$A$ & surface area $\left(\mathrm{cm}^{2}\right)$ & $R$ & universal gas constant $\left(0.0083144 \mathrm{~kJ} \mathrm{~mol}^{-1} \mathrm{~K}^{-1}\right)$ \\
\hline$E_{\mathrm{a}}$ & activation energy $\left(\mathrm{kJ} \mathrm{mol}^{-1}\right)$ & RMSE & root mean square error \\
\hline FT & fermentation threshold $(\mathrm{kPa})$ & $R_{\mathrm{O}_{2}}, R_{\mathrm{CO}_{2}}$ & respiration (consumption, \\
\hline$K_{\mathrm{m}, \mathrm{O}_{2}}$ & $\begin{array}{l}\text { Michaelis-Menten constant for the } \mathrm{pO}_{2} \mathrm{pkg} \text { at half of } \\
R_{\mathrm{O}_{2}}^{\max , T}(\mathrm{kPa})\end{array}$ & $R_{\mathrm{O}_{2}}^{\max , T}$ & $\begin{array}{l}\left(\mathrm{mmol} \mathrm{kg} \mathrm{kg}^{-1} \mathrm{~h}^{-1}\right) \\
\text { Michaelis-Menten constant for maximal value of } R_{\mathrm{O}_{2}}\end{array}$ \\
\hline$K_{\mathrm{mn}, \mathrm{CO}_{2}}$ & $\begin{array}{l}\text { Michaelis-Menten constant for the non-competitive } \\
\mathrm{CO}_{2} \text { inhibition }\end{array}$ & RQ & $\begin{array}{l}\left(\mathrm{mmol} \mathrm{kg}^{-1} \mathrm{~h}^{-1}\right) \\
\text { respiratory quotient }\end{array}$ \\
\hline$l$ & thickness $(\mathrm{cm})$ & $T$ & temperature $(\mathrm{K})$ \\
\hline$M$ & mass $(\mathrm{kg})$ & & \\
\hline $\begin{array}{l}p \\
P\end{array}$ & $\begin{array}{l}\text { partial gas pressure }(\mathrm{kPa}) \\
\text { permeability }\left(\mathrm{mmol} \mathrm{cm} \mathrm{cm}{ }^{-2} \mathrm{~h}^{-1} \mathrm{kPa}^{-1}\right)\end{array}$ & $\begin{array}{l}\text { atm } \\
\text { pkg }\end{array}$ & $\begin{array}{l}\text { outside the package } \\
\text { inside the package }\end{array}$ \\
\hline
\end{tabular}

\section{Materials and methods}

\section{Plant material}

Pears (Pyrus communis L. 'Rocha') were harvested in two consecutive years, 2006 and 2007, at commercial maturity (65 N firmness), from orchards located in the Western Region of Portugal $\left(39^{\circ} 11^{\prime} \mathrm{N}, 9^{\circ} 08^{\prime} \mathrm{W}\right)$. 'Rocha' pear has a long storage life and raw material is available for fresh-cut processing for up to ten months. Pears used in 2006 had been stored for 6 months at $-0.5^{\circ} \mathrm{C}, 93-$ $95 \% \mathrm{RH}$, and $2.5 \mathrm{kPa} \mathrm{O}_{2}$ plus $0.7 \mathrm{kPa} \mathrm{CO}_{2}$. Fruits processed in 2007 had been stored at $-0.5^{\circ} \mathrm{C}$ and $93-95 \% \mathrm{RH}$ in air for 5 weeks. Fruits removed from storage were allowed to ripen and were processed when the flesh firmness reached 47-49 N, since partially ripe pears are the most suitable for fresh-cut processing (Gorny et al., 2000; Soliva-Fortuny et al., 2004).

\section{Fresh-cut preparation and packaging}

Whole fruits were sanitized with $150 \mu \mathrm{L} \mathrm{L}^{-1} \mathrm{NaClO}$ for $2 \mathrm{~min}$, rinsed with tap water and air dried. Pears were cut in wedges with 5-10 $\mathrm{mm}$ of thickness, without skin removal. The fresh-cut pear wedges (30-265 g) were packed in low-density polyethylene (LDPE) (Dow Chemical Company, Midland, MI) pouches $(15 \times 15 \mathrm{~cm}$ or $20 \times 20 \mathrm{~cm})$, that were hermetically-sealed using an impulse heat sealer. The film thickness used in the experiments ranged from 27.0 to $102.1 \mu \mathrm{m}$.

Package size, film thickness, and fruit mass were varied to intentionally develop a range of oxygen concentrations (18$0.1 \mathrm{kPa}$ ). A gas sampling septum, consisting of a dab of silicone sealant $\left(G^{\circledR}\right.$ Silicone, NY) on a short strip of electrical tape (Scotch ${ }^{\circledR}$, St. Paul, MN), was attached to each pouch.

\section{Respiration rate determination}

A permeable system using LDPE of known permeability was used to obtain the respiratory rate of the enclosed produce. Rates of $\mathrm{O}_{2}$ uptake $\left(R_{\mathrm{O}_{2}}\right)$ and $\mathrm{CO}_{2}$ production $\left(R_{\mathrm{CO}_{2}}\right)$, and respiratory quotient ( $R Q=R_{\mathrm{CO}_{2}} / R_{\mathrm{O}_{2}}$ ), were calculated once steady-state $\mathrm{O}_{2}$ and $\mathrm{CO}_{2}$ partial pressures were achieved inside the packages, using the following equations (Beaudry et al., 1992; Joles et al., 1994; Lakakul et al., 1999):

$R_{\mathrm{O}_{2}}=\frac{\frac{P_{\mathrm{O}_{2}} \times A}{l} \times\left(p \mathrm{O}_{2} \mathrm{~atm}-p \mathrm{O}_{2 \mathrm{pkg}}\right)}{M}$

$R_{\mathrm{CO}_{2}}=\frac{\frac{P_{\mathrm{CO}_{2}} \times A}{l} \times\left(p \mathrm{CO}_{2 \mathrm{pkg}}-p \mathrm{CO}_{2} \mathrm{~atm}\right)}{M}$

where $R_{\mathrm{O}_{2}}$ and $R_{\mathrm{CO}_{2}}$ denote respiration rates $\left(\mathrm{mmol} \mathrm{kg}{ }^{-1} \mathrm{~h}^{-1}\right)$ of $\mathrm{O}_{2}$ and $\mathrm{CO}_{2}, P_{\mathrm{O}_{2}}$ and $P_{\mathrm{CO}_{2}}$ denote $\mathrm{O}_{2}$ and $\mathrm{CO}_{2}$ permeabilities
( $\left.\mathrm{mmol} \mathrm{cm} \mathrm{cm}{ }^{-2} \mathrm{~h}^{-1} \mathrm{kPa}^{-1}\right), A$ is the film area $\left(\mathrm{cm}^{2}\right), l$ is the film thickness $(\mathrm{cm}), p \mathrm{O}_{2} \mathrm{~atm}, p \mathrm{O}_{2} \mathrm{pkg}, p \mathrm{CO}_{2}$ atm and $p \mathrm{CO}_{2} \mathrm{pkg}$ are $\mathrm{O}_{2}$ and $\mathrm{CO}_{2}$ partial pressures ( $\mathrm{kPa}$ ) outside (atm) and inside (pkg) the package, and $M$ is the produce mass $(\mathrm{kg})$.

Three replicates of each combination of film thickness, film area, and fruit mass were stored at $0,5,10$ and $15^{\circ} \mathrm{C}$.

\section{Film permeability assessment}

Film permeability to $\mathrm{O}_{2}\left(P_{\mathrm{O}_{2}}\right)$ and $\mathrm{CO}_{2}\left(P_{\mathrm{CO}_{2}}\right)$ was measured using an isostatic method (Beaudry et al., 1992; Gavara et al., 1996). The permeation cell contained two external receiver chambers separated from a middle donor chamber by film samples. The middle chamber was initially flushed $\left(100 \mathrm{~mL} \mathrm{~min}^{-1}\right)$ with pure $\mathrm{N}_{2}$ to purge receiver chamber of oxygen. Once receiver chamber oxygen levels were reduced below detection limits, a mixture of $72 \mathrm{kPa} \mathrm{O}_{2}$ and $29 \mathrm{kPa} \mathrm{CO}_{2}$ was supplied to the donor chamber. The receiver gas composition was sampled $(100 \mu \mathrm{L})$, using a glass syringe, at $10 \mathrm{~min}$ intervals and analysed via sequential $\mathrm{O}_{2}$ and $\mathrm{CO}_{2}$ analyzers, using a paramagnetic $\mathrm{O}_{2}$ detector (Series 1100 , Servomex Co., Sussex, UK) and an infrared $\mathrm{CO}_{2}$ detector (ADC 255MK3, Analytical Development Co., Hoddesdon, UK), respectively, and connected in series (Lakakul et al., 1999). The diffusion rate of gases through the film was used to calculate the permeability coefficients, at $0.6,10,21$ and $23^{\circ} \mathrm{C}$, in controlled temperature chambers. The Arrhenius equation was used to fit the temperature influence on permeability (Beaudry et al., 1992; Joles et al., 1994; Cameron et al., 1995; Lakakul et al., 1999). The pre-exponential factor and activation energies were estimated via regression analysis, after linearization (Beaudry et al., 1992): $\ln \left(P_{i}\right)=$ $-E_{\mathrm{a}} / R T+\ln \left(P_{0, i}\right)$, where $P_{i}$ is permeability to $\mathrm{O}_{2}$ or $\mathrm{CO}_{2}$ $\left(\mathrm{mmol} \mathrm{cm} \mathrm{cm} \mathrm{cm}^{-2} \mathrm{~h}^{-1} \mathrm{kPa}^{-1}\right.$ ), $P_{0, i}$ is the pre-exponential factor, $E_{\mathrm{a}}$ is activation energy $\left(\mathrm{kJ} \mathrm{mol}^{-1}\right), R$ is ideal gas constant $\left(\mathrm{kJ} \mathrm{mol}^{-1} \mathrm{~K}^{-1}\right)$ and $T$ is temperature $(\mathrm{K})$.

\section{$\mathrm{O}_{2}, \mathrm{CO}_{2}$, and ethanol determination}

Headspace gas composition $\left(\mathrm{O}_{2}\right.$ and $\left.\mathrm{CO}_{2}\right)$ in individual packages was monitored daily using a gas analyzer, as described above, until steady-state was attained. The ethanol present in the headspace was sampled at steady-state and determined using a gas chromatograph system (HP-6890, Hewlett Packard, USA), equipped with a mass spectrometry detector.

\section{Experimental data modelling}

Respiration rate $\left(R_{\mathrm{O}_{2}}\right)$ was described as a function of $\mathrm{O}_{2}$ partial pressure by a Michaelis-Menten model (Eq. (3)), as suggested by Lee et al. (1991): 
$R_{\mathrm{O}_{2}}=\frac{R_{\mathrm{O}_{2}}^{\max , T} \times p \mathrm{O}_{2 \mathrm{pkg}}}{K_{\mathrm{m}, \mathrm{O}_{2}}+p \mathrm{O}_{2} \mathrm{pkg}}$

where $R_{\mathrm{O}_{2}}^{\max , T}$ is the maximal value of $R_{\mathrm{O}_{2}}\left(\mathrm{mmol} \mathrm{kg}^{-1} \mathrm{~h}^{-1}\right), p \mathrm{O}_{2} \mathrm{pkg}$ is the oxygen partial pressure inside packages $(\mathrm{kPa})$ and $K_{\mathrm{m}, \mathrm{O}_{2}}$ (apparent $\left.K_{\mathrm{m}}\right)$ is the $\mathrm{pO}_{2} \mathrm{pkg}$ at half of $R_{\mathrm{O}_{2}}^{\max , T}(\mathrm{kPa})$.

A non-competitive $\mathrm{CO}_{2}$ inhibition model (Peppelenbos et al., 1996) was also fitted to the data (Eq. (4)), to account for the possible effect of $\mathrm{pCO}_{2}$ on $\mathrm{O}_{2}$ consumption (Kerbel et al., 1988):

$R_{\mathrm{O}_{2}}=\frac{R_{\mathrm{O}_{2}}^{\max , T} \times \mathrm{pO}_{2} \mathrm{pkg}}{\left(K_{\mathrm{m}, \mathrm{O}_{2}}+p \mathrm{O}_{2} \mathrm{pkg}\right) \times\left(1+p \mathrm{CO}_{2} \mathrm{pkg} / K_{\mathrm{mn}, \mathrm{CO}_{2}}\right)}$

where $K_{\mathrm{mn}, \mathrm{CO}_{2}}$ is the Michaelis-Menten constant for the non-competitive $\mathrm{CO}_{2}$ inhibition.

Estimation of $R_{\mathrm{O}_{2}}^{\max , T}$ and $K_{\mathrm{m}, \mathrm{O}_{2}}$, based on experimental data, was performed by non-linear regression using the Levenberg-Marquardt method. The estimates obtained at each temperature were used to describe the temperature dependence of $R_{\mathrm{O}_{2}}^{\max , T}$ and $K_{\mathrm{m}, \mathrm{O}_{2}}$. In addition, the Michaelis-Menten models were fitted to the whole data set at all temperatures ( $n=129$ in 2006 and $n=154$ in 2007). In both models, $R_{\mathrm{O}_{2}}^{\max , T}$ was an exponential function of temperature, and $K_{\mathrm{m}, \mathrm{O}_{2}}$ could be modelled as either an exponential function of temperature or a constant, whereas $K_{\mathrm{mn}, \mathrm{CO}_{2}}$ was always a constant (Table 1 ). The predictions of respiratory parameters, $R_{\mathrm{O}_{2}}^{\max , T}$ and $K_{\mathrm{m} . \mathrm{O}_{2}}$, at $0,5,10$ and $15^{\circ} \mathrm{C}$, generated by solving the equations depicted on Table 4 , were used to calculate activation energies, through an Arrhenius plot (Eqs. (5) and (6)), and the temperature coefficient $\left(Q_{10}\right)$.

$\ln \left(R_{\mathrm{O}_{2}}^{\max , T}\right)=\ln \left(R_{\mathrm{O}_{2}}^{\max , 0}\right)-\frac{E_{\mathrm{a}}}{R}\left(\frac{1}{T}\right)$

$\ln \left(K_{\mathrm{m}, \mathrm{O}_{2}}\right)=\ln \left(K_{\mathrm{m}, \mathrm{O}_{2}}^{0}\right)-\frac{E_{\mathrm{a}}}{R}\left(\frac{1}{T}\right)$

where $R_{\mathrm{O}_{2}}^{\max , T}$ is the maximal value of $R_{\mathrm{O}_{2}}\left(\mathrm{mmol} \mathrm{kg} \mathrm{k}^{-1} \mathrm{~h}^{-1}\right), R_{\mathrm{O}_{2}}^{\max , 0}$ and $K_{\mathrm{m}, \mathrm{O}_{2}}^{0}$ are the pre-exponential factors, $K_{\mathrm{m}, \mathrm{O}_{2}}$ (apparent $K_{\mathrm{m}}$ ) is the $\mathrm{pO}_{2}$ pkg at half of $R_{\mathrm{O}_{2}}^{\max , T}(\mathrm{kPa}), E_{\mathrm{a}}$ is activation energy $\left(\mathrm{kJ} \mathrm{mol}^{-1}\right), R$ is ideal gas constant $\left(\mathrm{kJ} \mathrm{mol}^{-1} \mathrm{~K}^{-1}\right)$ and $T$ is temperature $(\mathrm{K})$.

The accuracy of parameters estimation was given by the ratio of the standard error to value estimate. The likelihood of the fit was ascertained by the root mean square error (RMSE) (Yang and Chinnan, 1988).

All statistical analyses were performed using the software package SPSS for Windows v.16.0 (SPSS, Chicago, IL).

\section{Results and discussion}

\section{Film permeability}

Permeability to $\mathrm{O}_{2}$ and $\mathrm{CO}_{2}$ and their temperature dependence are depicted in Fig. 1 . The predicted permselectivity $\left(\beta=P_{\mathrm{CO}_{2}} / P_{\mathrm{O}_{2}}\right)$
Table 2

Equations used to predict permeability as a function of temperature $(\mathrm{K})$ and activation energies for the films used in the experiments.

\begin{tabular}{lll}
\hline Predicting equation $\left(\mathrm{mmol} \mathrm{cm} \mathrm{cm}{ }^{-2} \mathrm{~h}^{-1} \mathrm{kPa}^{-1}\right)$ & $E_{\mathrm{a}}\left(\mathrm{kJ} \mathrm{mol}^{-1}\right)$ & $R^{2}$ \\
\hline$P_{\mathrm{O}_{2}}=0.067 \times e^{[-4423 / T]}$ & $E_{\mathrm{O}_{2}}=36.8$ & 0.930 \\
$P_{\mathrm{CO}_{2}}=0.118 \times e^{[-4153 / T)]}$ & ${E \mathrm{aCO}_{2}=34.5}$ & 0.923 \\
\hline
\end{tabular}

Table 3

Experimental rates of $\mathrm{O}_{2}$ uptake and $\mathrm{CO}_{2}$ production, respiratory quotient $\left(\mathrm{RQ}=\mathrm{R}_{\mathrm{CO}_{2}}\right.$ $R_{\mathrm{O}_{2}}$ ) and fermentation threshold (FT) for fresh-cut 'Rocha' pear stored at various temperatures.

\begin{tabular}{lllll}
\hline $\begin{array}{l}\text { Temperature } \\
\left({ }^{\circ} \mathrm{C}\right)\end{array}$ & $\begin{array}{l}R_{\mathrm{O}_{2}} \text { range } \\
\left(\mathrm{mmol} \mathrm{kg}^{-1} \mathrm{~h}^{-1}\right)\end{array}$ & $\begin{array}{l}R_{\mathrm{CO}_{2}} \text { range } \\
\left(\mathrm{mmol} \mathrm{kg}^{-1} \mathrm{~h}^{-1}\right)\end{array}$ & $\mathrm{RQ}^{\mathrm{a}}$ & $\mathrm{FT}(\mathrm{kPa})$ \\
\hline 0 & $0.02-0.06$ & $0.04-0.08$ & $1.37 \pm 0.02$ & 0.75 \\
5 & $0.03-0.18$ & $0.07-0.22$ & $1.38 \pm 0.03$ & 0.25 \\
10 & $0.04-0.49$ & $0.13-0.60$ & $1.26 \pm 0.02$ & 0.75 \\
15 & $0.09-0.95$ & $0.23-1.19$ & $1.18 \pm 0.01$ & 0.88 \\
\hline
\end{tabular}

a $\mathrm{RQ}$ are the mean $( \pm \mathrm{SE})$ of the experimental values measured at oxygen concentrations ranging from $18 \mathrm{kPa}$ to the fermentation threshold (Fig. 3).

at $0{ }^{\circ} \mathrm{C}$ was 4.7 and slightly lower $(4.4)$ at $20^{\circ} \mathrm{C}$. These permselectivities are similar to previous published results by Joles et al. (1994) ( 4.8 at $20^{\circ} \mathrm{C}$ and 4.9 at $0{ }^{\circ} \mathrm{C}$ ) and by Beaudry et al. (1992) (4.4 at $25^{\circ} \mathrm{C}$ and 5.2 at $0{ }^{\circ} \mathrm{C}$ ). The activation energy for $P_{\mathrm{O}_{2}}$ was $36.8 \mathrm{~kJ} \mathrm{~mol}^{-1}$ (Table 2), a value similar to those reported elsewhere (Beaudry et al., 1992; Joles et al., 1994; Lakakul et al., 1999), but slightly below the $40-50 \mathrm{~kJ} \mathrm{~mol}^{-1}$ range claimed for LDPE films used in MAP (Cameron et al., 1995). Activation energies for $P_{\mathrm{CO}_{2}}$ were $34.5 \mathrm{~kJ} \mathrm{~mol}^{-1}$ (Table 2), which were essentially identical to the values $35.0 \mathrm{~kJ} \mathrm{~mol}^{-1}$ (Lakakul et al., 1999) and $35.5 \mathrm{~kJ} \mathrm{~mol}^{-1}$ (Beaudry et al., 1992; Joles et al., 1994).

MAP design requires knowledge of permeability coefficients in the range of temperatures found during processing and marketing. Film suppliers usually provide $\mathrm{O}_{2}$ transmission rate determined at a single temperature (e.g. $23^{\circ} \mathrm{C}$ ), often outside the temperature range in the cold chain. Using these values to predict $\mathrm{O}_{2}$ concentration inside packages at $5{ }^{\circ} \mathrm{C}$, without correction of film $\mathrm{O}_{2}$ permeability, would lead to gross overestimation.

\section{Effect of oxygen concentration and temperature on respiratio rate}

Fruit at the same maturity stage were harvested in two consecutive years and stored for 6 months or 5 weeks, in 2006 and 2007, respectively. Despite the differences in storage durations, respiratory parameters did not differ significantly between years, likely because fruit were processed and analysed with similar maturities, as assessed by flesh firmness.

Table 1

Models used to describe the effects of oxygen concentration and temperature on the respiration rate of fresh-cut 'Rocha' pear.

\begin{tabular}{|c|c|c|c|c|}
\hline \multirow[t]{2}{*}{ Model label $^{\mathrm{a}}$} & \multirow[t]{2}{*}{ Model equation } & \multicolumn{3}{|c|}{ Model parameters } \\
\hline & & $R_{\mathrm{O}_{2}}^{\max , T}$ & $K_{\mathrm{m}, \mathrm{O}_{2}}$ & $K_{\mathrm{mn}, \mathrm{CO}_{2}}$ \\
\hline MM & $R_{\mathrm{O}_{2}}=\frac{R_{\mathrm{O}_{2}}^{\max , T} \times p \mathrm{O}_{2 \mathrm{pkg}}}{K_{\mathrm{m}, \mathrm{O}_{2}}+p \mathrm{O}_{2} \mathrm{pkg}}$ & $a \times e^{(b \times T)}$ & $q \times e^{(r \times T)}$ & - \\
\hline $\mathrm{MM}_{k}$ & $R_{\mathrm{O}_{2}}=\frac{R_{\mathrm{O}_{2}}^{\max , T} \times p \mathrm{O}_{2 \mathrm{pkg}}}{K_{\mathrm{m}, \mathrm{O}_{2}}+p \mathrm{O}_{2} \mathrm{pkg}}$ & $a \times e^{(b \times T)}$ & Constant & - \\
\hline MMNC & $R_{\mathrm{O}_{2}}=\frac{R_{\mathrm{O}_{2}}^{\mathrm{max}, \mathrm{T}} \times p \mathrm{O}_{2} \mathrm{pkg}}{\left(K_{\mathrm{m}, \mathrm{O}_{2}}+p \mathrm{O}_{2} \mathrm{pkg}\right) \times\left(1+p \mathrm{CO}_{2} \mathrm{pkg} / K_{\mathrm{mn}, \mathrm{CO}_{2}}\right)}$ & $a \times e^{(b \times T)}$ & $q \times e^{(r \times T)}$ & Constant \\
\hline $\mathrm{MMNC}_{k}$ & $R_{\mathrm{O}_{2}}=\frac{R_{\mathrm{O}_{2}}^{\max , T} \times p \mathrm{O}_{2 \mathrm{pkg}}}{\left(K_{\mathrm{m}, \mathrm{O}_{2}}+p \mathrm{O}_{2} \mathrm{pkg}\right) \times\left(1+p \mathrm{CO}_{2} \mathrm{pkg} / K_{\mathrm{mn}, \mathrm{CO}_{2}}\right)}$ & $a \times e^{(b \times T)}$ & Constant & Constant \\
\hline
\end{tabular}

${ }^{\mathrm{a}} \mathrm{MM}$ : Michaelis-Menten equation (Eq. (3)); MMNC: Michaelis-Menten equation with non-competitive inhibition by $\mathrm{CO}_{2}\left(\mathrm{Eq} .(4)\right.$ ). $\mathrm{MM}_{k}$ and $\mathrm{MMNC}_{k}$ have constant $K_{\mathrm{m}, \mathrm{O}_{2}}$. 
Table 4

Models predictions of $R_{\mathrm{O}_{2}}^{\max , T}, K_{\mathrm{m}, \mathrm{O}_{2}}$ and $K_{\mathrm{mn}, \mathrm{CO}_{2}}$ as a function of temperature (K) and models corresponding accuracies.

\begin{tabular}{|c|c|c|c|c|c|c|c|c|}
\hline Model $^{\mathrm{a}}$ & $R_{\mathrm{O}_{2}}^{\max , T}\left(\mathrm{mmol} \mathrm{kg}^{-1} \mathrm{~h}^{-1}\right)$ & $K_{\mathrm{m}, \mathrm{O}_{2}}(\mathrm{kPa})$ & $K_{\mathrm{mn}, \mathrm{CO}_{2}}{ }^{\mathrm{b}}(\mathrm{kPa})$ & $R^{2}$ & RMSE & $Q_{10} R_{\mathrm{O}_{2}}^{\max , T}$ & $E_{\mathrm{a}}^{\mathrm{c}} R_{\mathrm{O}_{2}}^{\max , T}$ & $E_{\mathrm{a}}{ }^{\mathrm{c}} K_{\mathrm{m}, \mathrm{O}_{2}}$ \\
\hline MM & $2.40 \times 10^{-26} \times e^{0.205 T}$ & $4.26 \times 10^{-30} \times e^{0.238 T}$ & - & 0.963 & 0.043 & 7.8 & 134.2 & 155.8 \\
\hline $\mathrm{MM}_{k}$ & $3.84 \times 10^{-24} \times e^{0.187 T}$ & 2.07 & - & 0.927 & 0.057 & 6.5 & 122.4 & - \\
\hline MMNC & $1.38 \times 10^{-24} \times e^{0.191 T}$ & $1.28 \times 10^{-30} \times e^{0.242 T}$ & $41.99(77 \%)$ & 0.966 & 0.039 & 6.8 & 125.0 & 158.4 \\
\hline $\mathrm{MMNC}_{k}$ & $2.43 \times 10^{-19} \times e^{0.149 T}$ & 1.27 & $14.26(42 \%)$ & 0.948 & 0.048 & 4.4 & 97.5 & - \\
\hline
\end{tabular}

${ }^{a} \mathrm{MM}$ - Michaelis-Menten model; MMNC - Michaelis-Menten model with non-competitive inhibition by $\mathrm{CO}_{2}$.

b Values within parenthesis indicate parameter accuracy (ratio of standard error to estimated value).

c Activation energies $\left(E_{\mathrm{a}}\right)$ of respiratory parameters were calculated using Arrhenius plots (Eqs. (5) and (6)).

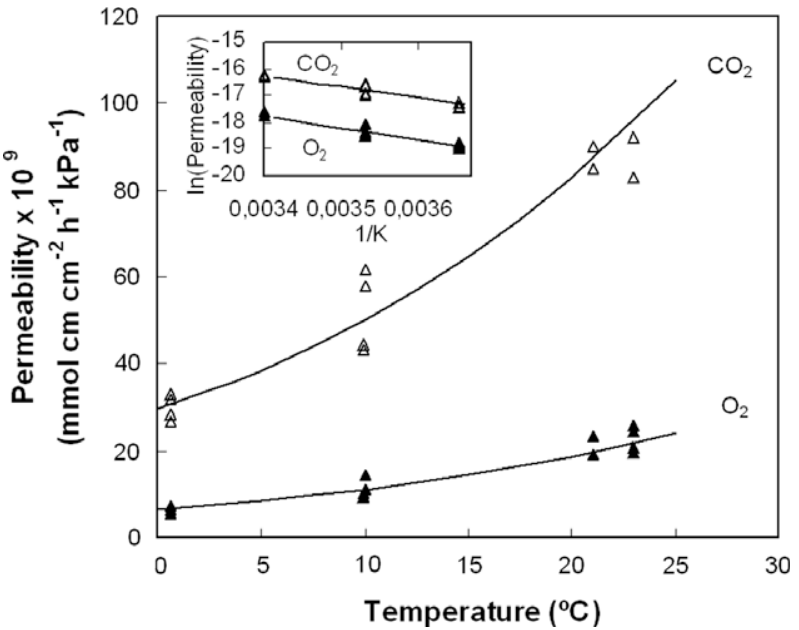

Fig. 1. Effect of temperature on film permeability to $\mathrm{O}_{2}$ (solid symbols) and $\mathrm{CO}_{2}$ (open symbols). Lines based on predicting equations presented in Table 2. Inset: Arrhenius plot of gases permeabilities.

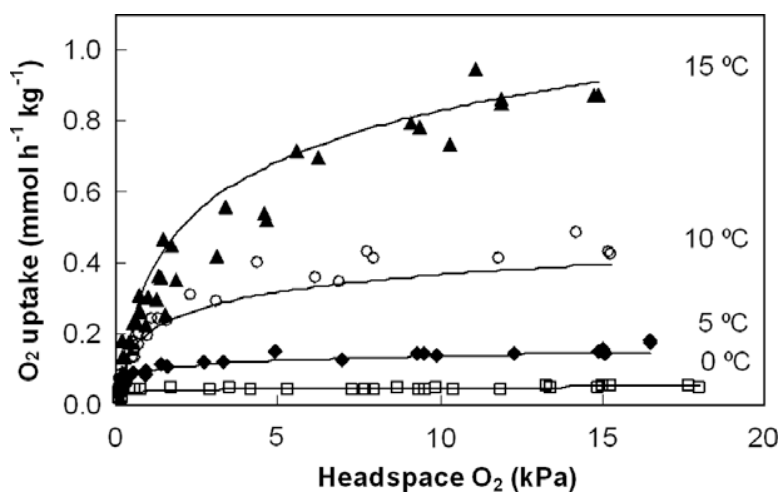

Fig. 2. Effect of steady-state $\mathrm{O}_{2}$ partial pressure and storage temperature on the rate of $\mathrm{O}_{2}$ uptake of 'Rocha' pear slices in sealed LDPE packages at $0^{\circ} \mathrm{C}(\square), 5^{\circ} \mathrm{C}(\bullet)$, $10{ }^{\circ} \mathrm{C}(\bigcirc)$ and $15^{\circ} \mathrm{C}(\boldsymbol{\Lambda})$ fitted with a Michaelis-Menten model.

Gas equilibrium concentration inside packages was reached by 4-5 days at $15^{\circ} \mathrm{C}, 6-8$ days at $10^{\circ} \mathrm{C}, 7-10$ days at $5{ }^{\circ} \mathrm{C}$, and $10-$ 11 days at $0^{\circ} \mathrm{C}$. The oxygen uptake rate increased with $\mathrm{pO}_{2} \mathrm{pkg}$ in a manner consistent with saturation kinetics (Fig. 2).

Respiration rates of fresh-cut 'Rocha' pear are shown in Table 3. These rates, expressed as $\mathrm{CO}_{2}$ production and obtained between 0.1 and $18 \mathrm{kPa} \mathrm{O}_{2}$, were similar to the range of value reported in air and in $2 \mathrm{kPa} \mathrm{O}_{2}$ for other fresh-cut pear varieties at 0 or $10^{\circ} \mathrm{C}$ (Gorny et al., 2000).

The respiratory quotient (RQ) for aerobic respiration of freshcut 'Rocha' pear stored at various temperatures ranged between 1.2 and 1.4 (Table 3), consistent with the usage of organic acids as major respiratory substrates (Fonseca et al., 2002). RQ values reported in the literature for whole 'Bartlett' pear varied from 0.8 at the initial climacteric to 1.4 at fully ripe stage (Biale, 1950). RQ values pertaining to intact 'Conference' pear lie between 0.7 and 0.8 (de Wild and Peppelenbos, 2001; Lammertyn et al., 2003). The reported RQ for fresh-cut 'Conference' pear above 1.7 after 1 day following processing (Soliva-Fortuny et al., 2007) are likely an analytical artefact or else a clear sign of fermentation.

Respiratory quotients and ethanol levels responded similarly to steady-state oxygen partial pressure $\left(\mathrm{pO}_{2}\right)$ (Fig. 3), and either variable may be used to determine the lower limit for aerobic respiration (Joles et al., 1994; Cameron et al., 1995). 'Fermentation threshold', the sudden increase in RQ or headspace ethanol concentration occurring when $\mathrm{pO}_{2}$ dropped below a certain level, ranged between 0.3 and $0.9 \mathrm{kPa}$ (Table 3). At elevated temperatures fermentation occurred at higher $\mathrm{pO}_{2}$ (Beaudry et al., 1992; Lakakul et al., 1999), as observed for 5 up to $15^{\circ} \mathrm{C}$ (Table 3). Fermentation threshold of whole 'Bartlett' pears varied between 0.3 and $1.7 \mathrm{kPa}$, at temperatures between 0 and $25^{\circ} \mathrm{C}$ (Kader et al., 1989). Temperature has a small influence on $\mathrm{CO}_{2}$ and $\mathrm{O}_{2}$ diffusion in 'Conference' pear as demonstrated by small activation energies obtained by $\mathrm{Ho}$ et al. (2006). Since the higher demand for $\mathrm{O}_{2}$ at elevated temperatures cannot be compensated by diffusion, fermentation occurs at higher $\mathrm{pO}_{2}$ (Beaudry et al., 1992).

Fresh-cut produce generally need lower $\mathrm{O}_{2}$ levels than whole fruits (Beaudry, 2000), due to absence of skin or less cuticle that could restrict gas diffusion (Burg and Burg, 1965; Schotsmans et al., 2003; Ho et al., 2006). The minimum $\mathrm{O}_{2}$ concentration tolerated by mature intact green 'Bartlett' pear at $25^{\circ} \mathrm{C}$ is 1.6 to $1.7 \mathrm{kPa}$, and by 'Passe Crassane' pear cell cultures is 1.1 to $1.3 \mathrm{kPa}$ (Boersig et al., 1988). The lower oxygen limit reported for sliced pear is $0.5 \mathrm{kPa}$ at $0-5^{\circ} \mathrm{C}$ (Beaudry, 2000; Gorny, 2001). Our results (Table 3 ) indicate that fresh-cut 'Rocha' pear should be packaged with $\mathrm{pO}_{2}$ higher than $0.8 \mathrm{kPa}$ at $0{ }^{\circ} \mathrm{C}, 0.3 \mathrm{kPa}$ at $5{ }^{\circ} \mathrm{C}, 0.8 \mathrm{kPa}$ at $10^{\circ} \mathrm{C}$ and $0.9 \mathrm{kPa}$ at $15^{\circ} \mathrm{C}$ to avoid fermentation. Consistent with the fermentation thresholds reported herein for 'Rocha' pear, $2.5 \mathrm{kPa} \mathrm{O}_{2}$ was considered acceptable for fresh-cut 'Conference' pear hold at $4{ }^{\circ} \mathrm{C}$, but $0 \mathrm{kPa} \mathrm{O}_{2}$ induced visual tissue damage (Soliva-Fortuny et al., 2007).

\section{Modelling the effects of oxygen and temperature on respiration rate}

The respiratory parameters $R_{\mathrm{O}_{2}}^{\max , T}, K_{\mathrm{m}, \mathrm{O}_{2}}$ and $K_{\mathrm{mn}, \mathrm{CO}_{2}}$ were estimated individually at each temperature, and their temperature dependence subsequently studied with the models presented in Table 1.

Exponential functions gave the best fit of $R_{\mathrm{O}_{2}}^{\max , T}$ in both experiments using the estimates of each temperature $\left(R^{2}>0.98\right.$, not shown). The temperature dependence of $R_{\mathrm{O}_{2}}^{\max , T}$ has been analysed according to the Arrhenius' law (Hertog et al., 1998; Jacxsens et al., 2000; Lammertyn et al., 2001; Ho et al., 2008). The rise in maximal rate of $\mathrm{O}_{2}$ uptake with temperature was equivalent to $Q_{10}$ values of 6.5-7.8 for data obtained in 2007 (Table 4 ). $Q_{10}$ values of 3.5-4.1 obtained in 2006 (not shown) are similar to those re- 

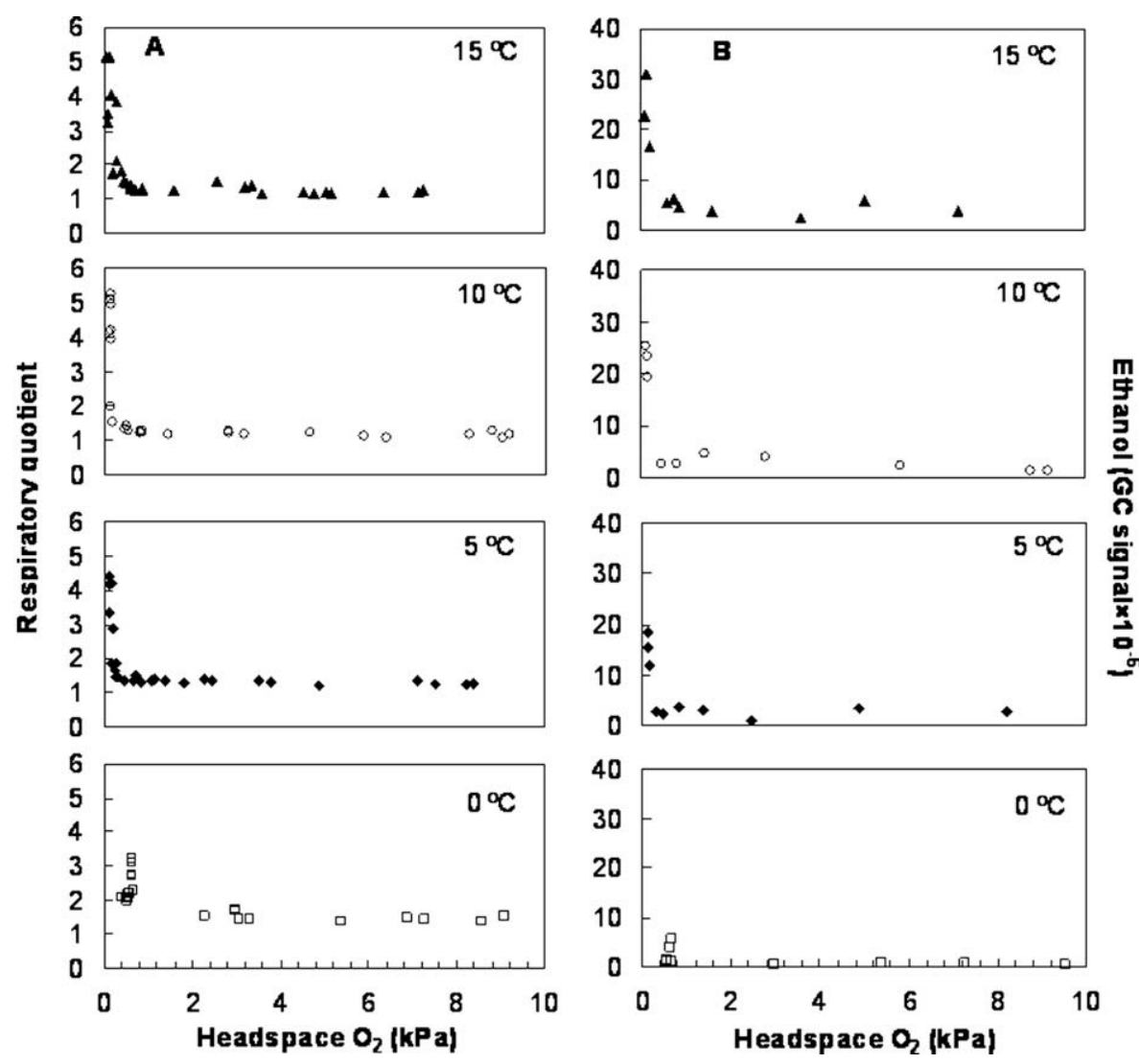

Fig. 3. Respiratory quotient (A) and headspace ethanol (B) as a function of steady-state $\mathrm{O}_{2}$ of packaged fresh-cut 'Rocha' pear.

ported for other fresh-cut pear varieties (Gorny et al., 2000). Similarly $Q_{10}$ of fresh-cut vegetables may range from 2.8 to 8.0 (Jacxsens et al., 2000). $E_{\mathrm{a}, \mathrm{RO}}{ }_{\text {max, } \mathrm{T}}$ of whole 'Conference' pear ranged from $64.6 \mathrm{~kJ} \mathrm{~mol}^{-1}$ (Lammertyn et al., 2001) to $80.2 \mathrm{~kJ} \mathrm{~mol}^{-1}$ (Ho et al., 2006); these values are only $48 \%$ to $86 \%$ of $E_{\mathrm{a}, \mathrm{RO}_{2}}{ }^{\max , \mathrm{T}}$ found in this study for fresh-cut 'Rocha' pear (Table 4). Respiration activation energy of common intact produce range between 50 and $89 \mathrm{~kJ} \mathrm{~mol}^{-1}$ (Exama et al., 1993; Fonseca et al., 2002), and can be as high as $135.9 \mathrm{~kJ} \mathrm{~mol}^{-1}$ in fresh-cut vegetables (Jacxsens et al., 2000).

Hertog et al. (1998) examined the temperature dependence of apparent $K_{\mathrm{m}}$ according to the Arrhenius' law and concluded that this variable can be treated as a constant. Non-competitive models published for intact 'Conference' pear (de Wild et al., 1999; Lammertyn et al., 2001, 2003; Ho et al., 2006, 2008) did not make $K_{\mathrm{m}, \mathrm{O}_{2}}$ and $K_{\mathrm{mn}, \mathrm{CO}_{2}}$ temperature-dependent. A constant $K_{\mathrm{m}, \mathrm{O}_{2}}$ was obtained for ten fresh-cut vegetables (Jacxsens et al., 2000) and packaged raspberry fruit for the temperature range from 0 to $20^{\circ} \mathrm{C}$ (Joles et al., 1994), while for blueberry a temperature effect on $K_{\mathrm{m}, \mathrm{O}_{2}}$ was found (Song et al., 1992; Cameron et al., 1994). Ho et al. (2006) indicated for cortex tissue of 'Conference' pear a $K_{\mathrm{m}, \mathrm{O}_{2}}$ of $1.16 \mathrm{kPa}$, similar to $K_{\mathrm{m}, \mathrm{O}_{2}}$ found for fresh-cut 'Rocha' pear (Table 4). Cytochrome $c$ oxidase, which is believed to be the rate determining enzyme in the respiratory pathways, has a high affinity to oxygen $\left(K_{\mathrm{m}, \mathrm{O}_{2}}=0.10-0.15 \mathrm{kPa}\right)$ and its activity does not change during hypoxia, when $\mathrm{pO}_{2}<0.25 \mathrm{kPa}$ (Nanos et al., 1994). However, diffusion limitations can lead to a much higher value of $K_{\mathrm{m}, \mathrm{O}_{2}}$ in intact pear $(6.2 \mathrm{kPa})$ than that in protoplasts $(\approx 0.007 \mathrm{kPa})$, and even higher than in the case of mitochondrial respiration (Lammertyn et al., 2001). Differences in the reported values of $K_{\mathrm{m}}$ can be accounted for by the joint effect of respiration at the cellular level and gas diffusion through the pear tissue and skin (Lammertyn et al., 2003).
The models in which there was a temperature dependence of $K_{\mathrm{m}, \mathrm{O}_{2}}$ were only marginally better than those where $K_{\mathrm{m}, \mathrm{O}_{2}}$ was constant (Table 4). Michaelis-Menten and non-competitive MichaelisMenten models were able to explain more than $93 \%$ of the total variability of the data and either model accurately predicted the experimental results (RMSE < 0.06). However, the non-competitive Michaelis-Menten model provided an estimate of $K_{\mathrm{mn}, \mathrm{CO}_{2}}$ with low accuracy (Table 4$)$. In addition, the $K_{\mathrm{mn}, \mathrm{CO}_{2}}$ values were very high (14.3-42.0 kPa), indicating a low inhibitory effect of $\mathrm{CO}_{2}$ on $\mathrm{O}_{2}$ consumption (Ho et al., 2008).

To discriminate between different types of inhibition it is necessary to know $\mathrm{O}_{2}$ consumption at two or more different $\mathrm{CO}_{2}$ concentrations and at three $\mathrm{O}_{2}$ concentrations (Peppelenbos et al., 1996). Since our data did not satisfy these requirements, it is not possible to assume an influence of $\mathrm{CO}_{2}$ on $\mathrm{O}_{2}$ consumption. However, given the accuracy of the simpler Michaelis-Menten model and the indications of minimal $\mathrm{CO}_{2}$ influence, the use of simpler model is preferred in this case (Fig. 2).

\section{Respiratory responses to low oxygen and implications for MAP}

Respiratory behavior as a function of oxygen concentration provides a basis to deduce the potential benefits of using MAP technologies in a given commodity. Low oxygen atmospheres could be useful if a sizeable reduction in respiration rate (e.g. 50\%) can be reached without the induction of fermentation (Beaudry, 2000). In cases where $K_{\mathrm{m}, \mathrm{O}_{2}}$ is much higher than fermentation threshold, a reduction in $\mathrm{pO}_{2}$ slows down metabolic activities without an increase in the RQ and fermentative compounds. The range of $\mathrm{pO}_{2}$ between $K_{\mathrm{m}, \mathrm{O}_{2}}$ and fermentation threshold is termed 'safe working atmosphere' (Beaudry, 2000). On the other hand, if $K_{\mathrm{m}, \mathrm{O}_{2}}$ is lower than the fermentation threshold any attempt to reduce $\mathrm{O}_{2}$ could 
Table 5

Michaelis-Menten model (MM) respiratory parameters for fresh-cut 'Rocha' pear stored at various temperatures.

\begin{tabular}{llll}
\hline $\begin{array}{l}\text { Temperature } \\
\left({ }^{\circ} \mathrm{C}\right)\end{array}$ & $\begin{array}{l}\text { Fermentation } \\
\text { threshold }(\mathrm{kPa})\end{array}$ & $\begin{array}{l}K_{\mathrm{m}, \mathrm{O}_{2}} \\
(\mathrm{kPa})\end{array}$ & $\begin{array}{l}\text { Safe working } \\
\text { atmosphere }(\mathrm{kPa})\end{array}$ \\
\hline 0 & 0.75 & 0.07 & No \\
5 & 0.25 & 0.24 & 0.01 \\
10 & 0.75 & 0.79 & 0.04 \\
15 & 0.88 & 2.59 & 1.71 \\
\hline
\end{tabular}

lead to fermentation. Fresh-cut 'Rocha' pear had a very narrow $(0.01-1.71 \mathrm{kPa})$ safe working atmosphere at the temperatures tested (Table 5). Low oxygen atmospheres did not offer any reduction in metabolic activity without the danger of inducing anaerobiosis, especially between 0 and $10^{\circ} \mathrm{C}$, temperatures normally found during storage and marketing. These data are consistent to the findings compiled by Gorny (2001), who also reported a poor efficacy of modified atmosphere for fresh-cut pear at $0-5{ }^{\circ} \mathrm{C}$.

In conclusion, respiration of fresh-cut 'Rocha' pear as function of oxygen concentration and temperature can be accurately predicted through Michaelis-Menten kinetics without inhibition by $\mathrm{CO}_{2}$. These data provide a foundation whereby sealed packages can be designed to avoid fermentative metabolism of fresh-cut 'Rocha' pear. However, given the respiratory kinetics of fresh-cut 'Rocha' pear, it is anticipated that low oxygen packaging is of little or no benefit in slowing down metabolism in this convenience produce.

\section{Acknowledgements}

This work was supported by Fundação para a Ciência e a Tecnologia (Portugal) via project grant PTDC/AGR-ALI/66144/2006 and the PhD grant SFRH/BD/22628/2005 to M.H. Gomes. The authors are grateful to Filipe Silva (CPF, Bombarral, Portugal) for providing pears.

\section{References}

Bai, J.-H., Saftner, R.A., Watada, A.E., Lee, Y.S., 2001. Modified atmosphere maintain quality of fresh-cut cantaloupe (Cucumis melo L.). Journal of Food Science 66 1207-1211.

Bai, J., Saftner, R.A., Watada, A.E., 2003. Characteristics of fresh-cut honeydew (Cucumis $x$ melo L.) available to processors in winter and summer and its quality maintenance by modified atmosphere packaging. Postharvest Biology and Technology 28, 349-359.

Beaudry, R.M., Cameron, A.C., Shirazi, A., Dostal-Lange, D.L., 1992. Modified atmosphere packaging of blueberry fruit: effect of temperature on package $\mathrm{O}_{2}$ and $\mathrm{CO}_{2}$. Journal of the American Society for Horticultural Science 117, 436441.

Beaudry, R.M., 2000. Responses of horticultural commodities to low oxygen: limits to the expanded use of modified atmosphere packaging. HortTechnology 10 491-500.

Biale, J.B., 1950. Postharvest physiology and biochemistry of fruits. Annual Review of Plant Physiology 1, 183-206.

Boersig, M.R., Kader, A.A., Romani, R.J., 1988. Aerobic-anaerobic respiratory transition in pear fruit and cultured pear fruit cells. Journal of the American Society for Horticultural Science 113, 869-873.

Brecht, J.K., 1995. Physiology of lightly processed fruits and vegetables. HortScience $30,18-22$.

Burg, S.P., Burg, E.A., 1965. Gas exchange in plant. Physiologia Plantarum 18, 870884.

Cameron, A.C., Beaudry, R.M., Banks, N.H., Yelanich, M.V., 1994. Modifiedatmosphere packaging of blueberry fruit: modeling respiration and package oxygen partial pressures as a function of temperature. Journal of the American Society for Horticultural Science 119, 534-539.

Cameron, A.C., Talasila, P.C., Joles, D.W., 1995. Predicting film permeability needs for modified-atmosphere packaging of lightly processed fruits and vegetables. HortScience 30, 25-34.

de Wild, H.P.J., Woltering, E.J., Peppelenbos, H.W., 1999. Carbon dioxide and 1-MCP inhibit ethylene production and respiration of pear fruit by different mechanisms. Journal of Experimental Botany 50, 837-844. de Wild, H.P.J., Peppelenbos, H.W., 2001. Improving the measurement of gas exchange in closed systems. Postharvest Biology and Technology 22, 111-119.

Del Nobile, M.A., Licciardello, F., Scrocco, C., Muratore, G., Zappa, M., 2007. Design of plastic packages for minimally processed fruits. Journal of Food Engineering 79, 217-224.

Exama, A., Arul, J., Lencki, R.W., Lee, L.Z., Toupin, C., 1993. Suitability of plastic films for modified atmosphere packaging of fruits and vegetables. Journal of Food Science 58, 1365-1370.

Fonseca, S.C., Oliveira, F.A.R., Brecht, J.K., 2002. Modelling respiration rate of fresh fruits and vegetables for modified atmosphere packages: a review. Journal of Food Engineering 52, 99-119.

Gavara, R., Catalá, R., Hernández-Muñoz, P.M., Hernández, R.J., 1996. Evaluation of permeability through permeation experiments: isostatic and quasiisostatic methods compared. Packaging Technology and Science 9, 215-224.

Gorny, J.R., Cifuentes, R.A., Hess-Pierce, B., Kader, A.A., 2000. Quality changes in fresh-cut pear slices as affected by cultivar, ripeness stage, fruit size, and storage regime. Journal of Food Science 65, 541-544.

Gorny, J.R., 2001. A summary of CA and MA requirements and recommendations for fresh-cut (minimally processed) fruits and vegetables. Postharvest Horticulture Series, vol. 22A. University of California, Davis, pp. 95-145.

Hertog, M.L.A.T.M., Peppelenbos, H.W., Evelo, R.G., Tijskens, L.M.M., 1998. A dynamic and generic model of gas exchange of respiring produce: the effects of oxygen, carbon dioxide and temperature. Postharvest Biology and Technology 14, 335-349.

Ho, Q.T., Verlinden, B.E., Verboven, P., Nicola, B.M., 2006. Gas diffusion properties at different positions in the pear. Postharvest Biology and Technology 41, 113120

Ho, Q.T., Verboven, P., Verlinden, B.E., Lammertyn, J., Vandewalle, S., Nicola, B.M., 2008. A continuum model for metabolic gas exchange in pear fruit. PLoS Computational Biology 4, 1-13.

Jacxsens, L., Devlieghere, F., Rudder, T.D., Debevere, J., 2000. Designing equilibrium modified atmosphere packages for fresh-cut vegetables subjected to changes in temperature. LWT - Food Science and Technology 33, 178-187.

Joles, D.W., Cameron, A.C., Shirazi, A., Petracek, P.D., 1994. Modified-atmosphere packaging of 'Heritage' red raspberry fruit: respiratory response to reduced oxygen, enhanced carbon dioxide, and temperature. Journal of the American Society for Horticultural Science 119, 540-545.

Kader, A.A., Zagory, D., Kerbel, E., 1989. Modified atmosphere packaging of fruits and vegetables. Critical Reviews in Food Science and Nutrition 28, 1-30.

Kerbel, E.L., Kader, A.A., Romani, R.J., 1988. Effects of elevated $\mathrm{CO}_{2}$ concentrations on glycolysis in intact 'Bartlett' pear fruit. Plant Physiology 86, 1205-1209.

Lakakul, R., Beaudry, R.M., Hernandez, R.J., 1999. Modeling respiration of apple slices in modified-atmosphere packages. Journal of Food Science 64, 105-110.

Lammertyn, J., Franck, C., Verlinden, B.E., Nicola, B.M., 2001. Comparative study of the $\mathrm{O}_{2}, \mathrm{CO}_{2}$ and temperature effect on respiration between 'conference' pear cell protoplasts in suspension and intact pears. Journal of Experimental Botany 362, 1769-1777.

Lammertyn, J., Scheerlinck, N., Jancsók, P., Verlinden, B.E., Nicola, B.M., 2003. A respiration-diffusion model for 'conference' pears I: model development and validation. Postharvest Biology and Technology 30, 29-42.

Lee, D.S., Haggar, P.E., Lee, J., Yam, K.L., 1991. Model for fresh produce respiration in modified atmospheres based on principles of enzyme kinetics. Journal of Food Science 56, 1580-1585.

Martínez-Ferrer, M., Harper, C., Pérez-Muñoz, F., Chaparro, M., 2002. Modified atmosphere packaging of minimally processed mango and pineapple fruits. Journal of Food Science 67, 3365-3371.

Nanos, G.D., Romani, R.J., Kader, A.A., 1994. Respiratory metabolism of pear fruit and cultured cells exposed to hypoxic atmospheres: associated change in activities of key enzymes. Journal of the American Society for Horticultural Science 119, 288-294.

Peppelenbos, H.W., van't Leven, J., 1996. Evaluation of four types of inhibition for modelling the influence of carbon dioxide on oxygen consumption of fruits and vegetables. Postharvest Biology and Technology 7, 27-42.

Schotsmans, W., Verlinden, B.E., Lammertyn, J., Nicola, B.M., 2003. Simultaneous measurement of oxygen and carbon dioxide diffusivity in pear fruit tissue. Postharvest Biology and Technology 29, 155-166.

Soliva-Fortuny, R., Alòs-Saiz, N., Espachs-Barroso, A., Martín-Belloso, O., 2004. Influence of maturity at processing on quality attributes of fresh-cut conference pears. Journal of Food Science 69, 290-294.

Soliva-Fortuny, R., Ricart-Coll, M., Elez-Martínez, P., Martín-Belloso, O., 2007. Internal atmosphere, quality attributes and sensory evaluation of MAP packaged fresh-cut conference pears. International Journal of Food Science and Technology 42, 208-213.

Song, Y., Kim, H.K., Yam, K.L., 1992. Respiration rate of blueberry in modified atmosphere at various temperatures. Journal of the American Society for Horticultural Science 117, 925-929.

Teixeira, G.H.A., Durigan, J.F., Alves, R.E., O'Hare, T.J., 2007. Use of modified atmosphere to extend shelf life of fresh-cut carambola (Averrhoa carambola L. cv. Fwang Tung). Postharvest Biology and Technology 44, 80-85.

Yang, C.C., Chinnan, M.S., 1988. Modeling the effect of $\mathrm{O}_{2}$ and $\mathrm{CO}_{2}$ on respiration and quality of stored tomatoes. Transactions of the American Society of Agricultural Engineers 31, 920-925. 